\title{
Analisis Kadar Kurkuminoid dalam Filtrat, Residu dan Campuran Filtrat-Residu Jamu Kunir Asem
}

\author{
Elisa Almeyda ${ }^{1)}$ dan Elok Widayanti ${ }^{1)}$ \\ ${ }^{1)}$ Politeknik Kesehatan, Kementerian Kesehatan Malang, Indonesia \\ e-mail : elok.widayanti@gmail.com; elisaalmeyda123@gmail.com
}

\begin{abstract}
ABSTRAK
Jamu kunir asem merupakan jamu yang bermanfaat untuk meredakan nyeri pada saat menstruasi karena mengandung kurkuminoid yang bersifat analgetika, antipiretika dan antiinflamasi. Tujuan dari penelitian ini yaitu menganalisis perbedaan kadar kurkuminoid pada filtrat, residu dan campuran filtrat-residu jamu kunir asem. Sebanyak 2 gram sampel diekstraksi dengan $40 \mathrm{ml}$ kloroform kemudian diuapkan hingga didapatkan ekstrak dan dilarutkan dengan etanol p.a. Penetapan kadar kurkuminoid pada sampel menggunakan metode Spektrofotometri Uv-Visible pada panjang gelombang $462 \mathrm{~nm}$. Kadar kurkuminoid terendah pada filtrat sebesar 11,346 ppm dan tertinggi pada residu sebesar 49,047 ppm sedangkan campuran filtrat-residu sebesar 22,549 $\mathrm{nm}$. Hasil analisis One Way Anova menunjukkan bahwa rata-rata konsentrasi kurkuminoid pada campuran filtrat-residu, filtrate dan residu jamu kunir asem berbeda secara signifikan.
\end{abstract}

Kata kunci: Filtrat; jamu kunir asem; kurkuminoid; residu

\section{Analysis of Curcumin Levels in Filtrat, Residues and Mixed in Herb of Turmeric Tamarind}

\begin{abstract}
Turmeric tamarind is a useful herb to relieve pain during menstruation because it contains analgesic, antipyretic and anti-inflammatory curcuminoids. The purpose of this study was to analyze differences in levels of curcuminoids in filtrate, residues and mixture of filtrate residues of tamarind turmeric. A total of 2 grams of sample was extracted with $40 \mathrm{ml}$ of chloroform and then evaporated until an extract was obtained and dissolved with ethanol p.a. Determination of curcuminoid levels in samples using the Uv-Visible Spectrophotometry method at a wavelength of $462 \mathrm{~nm}$. The lowest curcuminoid content in the filtrate was $11.346 \mathrm{ppm}$ and the highest in the residue was $49.047 \mathrm{ppm}$ while the mixture of the filtrate-residue was $22.549 \mathrm{~nm}$. The results of the One Way Anova analysis showed that the mean curcuminoid concentration in the mixture of filtrate-residue, filtrate and residues of tamarind turmeric was significantly different.
\end{abstract}

Keywords: curcuminoids, turmeric tamarind, filtrate, residue

(Article History：Received 05-09-2020; Accepted 07-11-2020; Published 08-11-2020)

\section{PENDAHULUAN}

Jamu merupakan minuman tradisional yang umum ditemui di masyarakat. Jamu dikenal sebagai minuman herbal yang digunakan sebagai obat untuk berbagai penyakit. Jamu kunir asem merupakan salah satu jenis jamu yang berkhasiat dalam meredakan nyeri menstruasi dikarenakan kunyit dan asam jawa dalam jamu mengandung bahan aktif yang berfungsi sebagai analgetika, antipiretika, dan antiinflamasi (Yusuf \& Nurkhasanah, 2016).
Jamu kunir asem banyak dijual di berbagai tempat, mulai dari jamu gendong maupun jamu saset yang diproduksi oleh industri besar. Umumnya jamu kunir asem banyak dijumpai dalam bentuk cair bersifat mudah mengendap sehingga dalam penyajiannya penjual akan mengkocok jamu terlebih dahulu kemudian disajikan dalam gelas (Torri, 2013). Ada dua cara mengkonsumsi jamu cair di masyarakat yaitu dikocok terlebih dahulu atau diendapkan 
dalam hal ini hanya cairan diatas endapan yang dikonsumsi.

Jamu kunir asem dibuat dengan bahan dasar rimpang kunyit dan asam jawa dimana keduanya mengandung bahan aktif yang bermanfaat bagi tubuh. Asam jawa mengandung $8-14 \%$ asam tartarat, $30-40 \%$ gula, serta sejumlah kecil asam sitrat dan kalium bitartrat sehingga berasa sangat asam (Rukmana, 2005). Rimpang kunyit mengandung kurkumin, desmetoksi kurkumindan bisdesmetoksi-kurkumin yang ketiganya sering disebut sebagai kurkuminoid (Harini et al., 2012). Menurut (Rivai et al., 2019), kurkuminoid tidak mudah larut dalam air namun mudah larut dalam pelarut organik seperti metilsulfoksida, aseton, etanol, dan minyak. Sedangkan dalam pengolahan jamu kunir asem menggunakan pelarut air.

Penelitian yang telah dilakukan oleh Harini tentang analisis terhadap kurkuminoid pada filtrat rimpang kunyit menggunakan metode Spektrofotometri UV Vis. Selain itu (Setiawan, 2010) juga melakukan penelitian mengenai kadar kurkuminoid pada filtrat serbuk kunyit dengan metode Spektrofotometri Uv-Visible.

Berdasarkan latar belakang diatas peneliti hendak melakukan penelitian tentang analisis kadar kurkuminoid tidak hanya pada pada filtrat melainkan juga terhadap residu dan campuran filtrat-residu jamu kunir asem menggunakan metode spektrofotometri.

\section{METODE PENELITIAN}

Bahan yang digunakan dalam penenlitian ini yaitu sampel jamu kunir asem yang diambil di Desa Ringinkembar Kecamatan Sumbermanjing Wetan Kabupaten Malang, standar kurkumin, etanol p.a dan kloroform. Alat yang digunakan dalam penelitian ini yaitu alat-alat gelas, spektrofotometer Uv-Visible, neraca analitk, waterbath dan oven.

\section{Pembuatan Larutan Uji}

Sampel jamu kunir asem sebanyak 1500 $\mathrm{ml}$ dibagi menjadi tiga bagian. Masing-masing sampel didiamkan selama 2 jam. Sampel residu dan filtrat disarimg kemudian sampel residu dikeringkan dalam suhu $50^{\circ} \mathrm{C}$ sedangkan sampel campuran dilakukan pengocokan.
Sampel ditimbang sebanyak 2 gram kemudian dilakukan ekstraksi padat cair untuk sampel residu dan ektraksi cair-cair untuk sampel filtrat dan campuran. Masing-masing sampel diekstrasi dengan kloroform sebanyak tiga kali. Ektraksi pertama menggunakan 20 $\mathrm{ml}$ kloroform selama 5 menit. Ekstraksi kedua menggunakan $10 \mathrm{ml}$ kloroform selama 5 menit dan ekstraksi ketiga menggunakan $10 \mathrm{ml}$ kloroform selama 3 menit.

Lapisan organik yang didapatkan kemudian diuapkan menggunakan waterbath suhu $50^{\circ} \mathrm{C}$. Kemudian ekstrak yang didapatkan dilarutkan dengan $5 \mathrm{ml}$ etanol p.a dan diencerkan hingga $50 \mathrm{ml}$. masing-masing sampel direplikasi tiga kali.

\section{Pembuatan Larutan Standar}

Membuat larutan induk kurkumin 100 ppm dengan etanol p.a kemudian dibuat seri konsentrasi yaitu 10 ppm, 20 ppm, 30 ppm, 40 ppm, 50 ppm dan 60 ppm.

\section{Penentuan Kadar Kurkuminoid}

Penentuan kadar kurkuminoid ditentukan menggunakan Spektrofotometer Uv-Visible. Penentuan panjang gelombang maksimum dilakukan analisis menggunakan larutan standar $60 \mathrm{ppm}$ dengan panjang gelombang 400-800 nm. Kemudian larutan blanko, seri standar dan larutan sampel dianalisis dengan panjang gelombang maksium.

\section{HASIL DAN PEMBAHASAN}

Penelitian ini menggunakan sampel jamu kunyit asam yang dibagi perlakuannya menjadi filtrat, residu dan campuran filtrat residu.

Filtrat merupakan cairan yang didapatkan setelah proses filtrasi atau penyaringan (Fitoni et al., 2013). Filtrat jamu kunir asem merupakan cairan berwarna kuning kecoklatan yang didapatkan setelah dilakukan penyaringan pada jamu kunir asem. Jamu yang dijual secara tradisional umumnya dipasarkan oleh pedagang jamu gendong dalam bentuk cair yang dikemas dalam botol (Tarigan et al., 2008).

Residu merupakan materi pengotor atau sisa dari suatu proses pengolahan bahan (Fatimah et al., 2017). Residu jamu kunir asem merupakan endapan berwarna kuning kecoklatan sisa hasil penyaringan jamu kunir 
asem. Sebelum dilakukan analisis terhadap suatu residu biasanya dilakukan pengeringan terlebih dahulu. Hal ini bertujuan untuk menghilangkan pelarut yang tersisa hingga didapatkan serbuk kering. Serbuk merupakan bahan kering yang dihaluskan hingga terbentuk butiran-butiran kecil (Tarigan et al., 2008).

Campuran merupakan gabungan dari dua bahan atau lebih dimana masing masing komponennya dapat dipisahkan (Fadeli, 2008). Campuran filtrat-residu jamu kunir asem merupakan larutan campuran yang didapatkan setelah proses pengkocokan. Campuran ini mengandung dua komponen utama yaitu filtrat dan residu jamu kunir asem.

\section{Pembuatan Larutan Uji}

Sampel jamu kunir asem diekstraksi dengan kloroform dikarenakan kurkuminoid lebih larut dalam pelarut organik. Selain itu, kloroform memiliki bobot jenis 1,476 g/mL sehingga tidak bercampur dengan air yang terdapat pada jamu tradisional kunir asam. Kloroform dapat mengekstraksi maksimal kurkuminoid tetapi tidak dapat mengekstraksi kandungan lain yang terdapat pada jamu tradisional kunir asam (Yusuf \& Nurkhasanah, 2016).

Lapisan organik sampel yang telah didapatkan kemudian diuapkan di atas waterbath dengan suhu $50^{\circ} \mathrm{C}$ hingga pelarut menguap dan didapatkan ekstrak kurkuminoid (Gambar 1). Menurut (Adnina, 2018), kurkuminoid mudah terdegradasi pada suhu tinggi. Kurkumin akan mengalami siklisasi kurkumin atau degradasi struktur (Rahayu et al., 2010). Selain itu perlakuan pemanasan berupa pendidihan serbuk kunyit selama 20 menit menyebabkan kandungan kurkumin mengalami penurunan sebesar 32\% (Suresh et al., 2007). Kemudian ekstrak dilarutkan dengan etanol p.a.
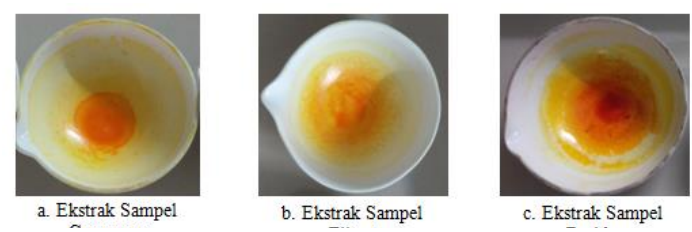

Gambar 1 Ekstrak Jamu Kunir Asem

\section{Penentuan Kadar Kurkuminoid}

Dalam penelitian ini menggunakan standar kurkumin dikarenakan menurut
(Departemen Kesehatan Republik Indonesia, 2008) menyatakan bahwa kunyit sebagai bahan dasar dari jamu kunir asem mengandung $6.60 \%$ kurkuminoid yang dihitung sebagai kurkumin.

Spektrofotometri UV-Visible melibatkan pengukuran jumlah radiasi ultraviolet REM yang diserap oleh zat (Behera et al., 2012). Kurva standar diukur menggunakan larutan standar $10 \mathrm{ppm}, 20$ ppm, $30 \mathrm{ppm}, 40 \mathrm{ppm}, 50 \mathrm{ppm}$ dan $60 \mathrm{ppm}$ pada panjang gelombang maksimum yaitu 462 $\mathrm{nm}$. Persamaan kurva standar $\mathrm{Y}=0.0837 \mathrm{X}$ 0.089 (Gambar 2).

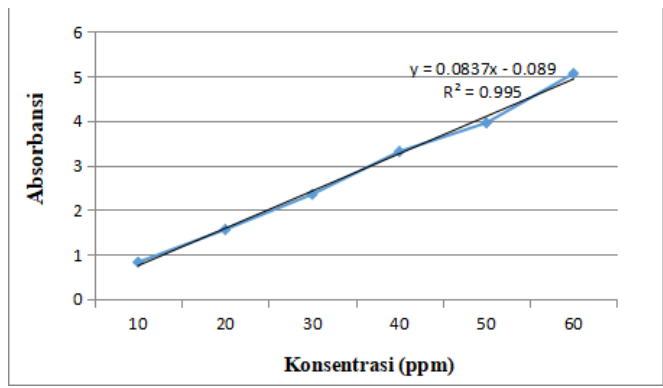

Gambar 2 Kurva Standar Kurkuminoid

Penentuan kadar kurkuminoid pada sampel diperoleh data seperti tercantum pada Tabel 1.

Tabel 1 Rata-Rata Konsentrasi Kurkuminoid dalam Jamu Kunir Asem

\begin{tabular}{llcc}
\hline No & Sampel & $\begin{array}{c}\text { Rata-Rata } \\
\text { Konsentrasi } \\
(\mathbf{p p m})\end{array}$ & $\begin{array}{c}\text { Standar } \\
\text { Deviasi }\end{array}$ \\
\hline $\mathbf{1}$ & Campuran & 22,549 & $\pm 4,334$ \\
$\mathbf{2}$ & Filtrat & 11,346 & $\pm 0,496$ \\
$\mathbf{3}$ & Residu & 49,047 & $\pm 15,929$ \\
\hline
\end{tabular}

Sampel filtrat mempunyai rata-rata konsentrasi kurkuminoid terendah sebesar 11,346 ppm sedangkan sampel residu mempunyai rata-rata konsentrasi kurkuminoid tertinggi sebesar 49,047 ppm.

Dari analisis One Way Anova dengan tingkat kepercayaan $95 \%$ diperoleh nilai $\mathrm{p}=$ 0,007 dimana lebih kecil dari 0,05. Hal menunjukkan bahwa konsentrasi kurkuminoid pada campuran filtrat-residu, filtrate dan residu jamu kunir asem berbeda secara signifikan. Hal tersebut dapat dikarenakan sifat kurkuminoid yang tidak terlalu larut dalam air sehingga kandungannya 
dalam jamu kunir asem lebih besar dalam residu. Perbedaan perlakuan pada jamu kunyit asam yakni campuran filtrat-residu, filtrat dan residu menyebabkan konsentrasi rata-ratanya mempunyai perbedaan.

\section{KESIMPULAN}

Berdasarkan hasil penelitian pada jamu kunir asem, didapatkan kadar kurkuminoid terendah terdapat pada filtrat sebesar 11,346 ppm dan tertinggi pada residu sebesar 49,047 ppm sedangkan campuran filtrat-residu sebesar 22,549 ppm. Analisis menggunakan metode One Way Anova diketahui bahwa kadar filtrat, residu dan campuran filtratresidu jamu kunir asem berbeda secara signifikan.

\section{DAFTAR PUSTKA}

Adnina, E.F. 2018. Uji aktivitas dan identifikasi kurkuminoid pada rimpang Kunyit Putih (Curcuma zedoaria (Christm.) Berg) sebagai antikanker payudara T47D [Desertasi]. Universitas Islam Negeri Maulana Malik Ibrahim.

Behera, S., S. Ghanty, F. Ahmad, S. Santra \& S. Banerjee. 2012. UV-visible spectrophotometric method development and validation of assay of paracetamol tablet formulation. $J$ Anal Bioanal Tech., 3: 151-157.

Departemen Kesehatan Republik Indonesia, 2008. Farmakope Herbal Indonesia. Edisi I. 73. Departemen Kesehatan Republik Indonesia, Jakarta.

Fadeli, Y. 2008. Daya Analgesik dari Campuran Ekstrak Rimpang Kunyit dan Ekstrak Daging Buah Asam Jawa dengan Komposisi 20\%: 10\% dan Optimasi Komposisi Menggunakan Metode Simplex Lattice Design. Simplex Lattice Des. [Skripsi].

Fatimah, S., M. Rahayu \& A.L.T. Rinding. 2017. Analisis Sakarin dalam Jamu Kunyit Asam yang Dijual di Malioboro dan di Pasar Beringharjo Yogyakarta. Biomedika, 10(1): 30-35.
Fitoni, C.N., M.T. Asri \& M.T. Hidayat. 2013. Pengaruh pemanasan filtrat rimpang kunyit (Curcuma llonga) terhadap pertumbuhan koloni bakteri Coliform secara in vitro. LenteraBio, 2(3): 217-221.

Harini, B.W., D. Rini \& W.W. Lucia. 2012. Aplikasi Metode Spektrofotometri Visibel untuk Mengukur Kadar Curcuminoid pada Rimpang Kunyit (Curcuma domestica), in: 1. Presented at the Seminar Nasional Aplikasi Sains \& Teknologi Periode III, Yogyakarta.

Rahayu, W.S., D. Hartanti \& M. Setiowati. 2010. Pengaruh Lama Dan Tempat Penyimpanan Terhadap Kadar Kurkuminoid Pada Sediaan Jamu Serbuk Merk "a" Yang Mengandung Simplisia Rimpang Kunyit (Curcuma Domestica, Val.). Pharmacy, 7(2): 3546.

Rivai, H., Misfadhila, S., Sari, L.K., 2019. Analisis Kualitatif dan Kuantitatif Kandungan Kimia dari Ekstrak Heksan, Aseton, Etanol dan Air dari Rimpang Kunyit (Curcuma domestica Val). Universitas Andalas, Padang.

Rukmana, R. 2005. Budidaya asam jawa. Kanisius, Yogyakarta.

Setiawan, I.F. 2010. Penentuan Kadar Kurkuminoid dalam Kunyit dengan Spektrofotometri Derivatif [Skripsi]. Departemen Kimia Fakultas Matematika Dan Ilmu Pengetahuan Alam, Institut Pertanian Bogor, Bogor.

Suresh, D., H. Manjunatha \& K. Srinivasan. 2007. Effect of heat processing of spices on the concentrations of their bioactive principles: Turmeric (Curcuma longa), red pepper (Capsicum annuum) and black pepper (Piper nigrum). J. Food Compos. Anal., 20: 346-351.

Tarigan, J.B., C.F. Zuhra \& H. Sihotang. 2008. Skrining fitokimia tumbuhan yang digunakan oleh pedagang jamu gendong untuk merawat kulit wajah di Kecamatan Medan Baru. 3: 1-6.

Torri, M.C. 2013. Knowledge and risk perceptions of traditional jamu medicine among urban consumers. Eur. J. Med. Plants, 25-39. 
Yusuf, F.M. \& N. Nurkhasanah. 2016. Evaluasi Kadar Kurkumin dalam Jamu Tradisional Kunir Asam yang Dijual di Pasar Kota Gede Bulan Februari 2015. Pharm. Sci. Res. 2: 115-123. 